\title{
Growth Drivers in Selected Death Care Businesses in the Philippines
}

\author{
Isaias Lagsa Borres \\ Graduate School, Department of Management, Our Lady of Fatima University, Valenzuela City, Philippines
}

\section{Email address:}

Docborres@yahoo.com

\section{To cite this article:}

Isaias Lagsa Borres, Growth Drivers in Selected Death Care Businesses in the Philippines. European Business \& Management. Vol. 6, No. 5, 2020, pp. 116-127. doi: 10.11648/j.ebm.20200605.12

Received: August 20, 2020; Accepted: September 5, 2020; Published: September 19, 2020

\begin{abstract}
Death Care business refers to organization or company which provides act of assistance in cognizant to demise, burials, crematory, interment and mausoleum. The growth in the death care industry is fueled by various factors such as internal and external factors. External factors, are aging population, robust economy, increase in disposable income, population growth, and death rate increment.. Internal factors: strategic vision, marketing strategy and branding product/ service, financial performance, human capital, and customer base. This research paper aimed to determine the growth drivers of death care businesses in the Philippines and to formulate alternative strategic management plans. This study employed descriptive-evaluative method and utilized the SWOT, PESTEL, Five Forces Porter's model and the balanced scorecard. The paper concludes that word of mouth as the most convincing factor. Death care business is stable, profitable and still growing in the Philippines. Death rate went high due to the growth drivers. All items under the aspect of strategies implemented were rated 'great extent', emphasizing that any available strategic formulation which can be applied and utilized by a certain death care company would definitely be adopted so as to address competition. The respondent death care companies have a 'strong' leverage on market positioning. This was indicated by the grand mean of 2.91 (strong). It is recommended that death care businesses shall enable themselves to assert current business situations in order to develop appropriate strategic actions, novel strategies, ability to foresee the future trends in the funeral industry, and appropriate measures must be implemented in Advertising, technology and price standardization.
\end{abstract}

Keywords: Death Care Business, PESTEL Analysis, Balanced Score Card, and SWOT

\section{Introduction}

All things come to an end, no one and nothing can escape because death is a certainty in life. Competition in the death care business is increasing in number much of the emergence of small entrepreneurs, entering in this venture. The high cost of inflation affects the traditional values of Filipino way of interment of the bereaved family thus, changed to cremation. Funeral and wake services prices have increased by around $10 \%$ [12]. However, with the many entrants in death care, it had kept the price increase into a minimum. Issues on the proper disposal of cadaver and the unclaimed dead bodies were already in advance stages of decomposition have increased [8]. Problems on high funeral costs on the medico-legal cases due war on drugs and sales decline because the free funeral service from the local government, have aggravated the situation [15]. These facts indeed affect the image of the funeral homes in the Philippines. More so, Filipino owners of the funerals found it difficult to apply marketing functions such as advertisement in the social media or simply the brochure or even a simple tarpaulin to increase awareness of such product and services they offer. This research paper aimed to determine the growth drivers of death care businesses in the Philippines and to formulate alternative strategic management plans [5].

The growth in the death care industry is fueled by various factors such as internal and external factors. In the external factors, they are aging population, robust economy, urbanization, increase in disposable income, unshakeable population growth, \& death rate increment and demands that are not met for death care products and services.(marketreportsonline.com/publisher) While for the internal factors, are the strategic vision, marketing strategy and branding product/ service offering, financial performance, 
human capital, and customer base [15]. Continuous assessment of the value drivers of the firm is essential to its growth and development. The process of evaluation includes both a qualitative and a quantitative companies assessment, and indeed a part of any business firm owner's standard operating procedure, which is in fact an important firm's management activity and a useful tool. And with the proper valuation assessment, it can supply the firm owners with worthy and surety actionable fact which accentuates the authentic innate value of the company and certainly aggrandize returns.

This business is huge and increasing in number [11]. When Manny Villar, was named as the Real Property of the Year, he mentioned that this industry is stable, death rate is consistent and no ups and downs, (bworldonline.com/content.php.section). Death Care business refers to organization or company which provides act of assistance in cognizant to demise, burials, crematory, interment and mausoleum. Majority are family-owned, sole proprietorship, while others are operated by corporations and is run by paid staff on an hourly basis. Some were previously sold to large corporations by the children or heirs of the late owner/s who decided not to continue the family business [10]. This business is the industry that has multiple sub sector. They function as chandler of burial and memorial products, prepare cremation or interment, provide space in memorial services and, resting on the demands of the relatives' wants. "e-Burol" service has been introduced to enable relatives and friends who cannot visit for some reason to the wake, can view the remains anywhere through website [2]. The facility entails a user-name password that is given only to the family. Demand for funeral services is inelastic, making the group recession resistant, though not recession proof. [12]. There will always be clients in demand of death care services. At present, this industry is experiencing a transformation and innovation process People convey with new values when it comes to funeral service. More often than non-, traditional burials are always the preferred option practice in the Philippines, but cremation, for a practical reason, is the choice, and becoming more popular for many Filipinos nowadays. A shift from wood to plastic coffin to a more eco-friendlier funerals, some caskets are made from recycled newspapers; from. one package to several packages for multiple needs, the specific customer choice can be drawn up and some Filipino families are changing from the old funeral rituals to a life celebrations instead; and the personalization concept of funerals or the "Do it yourself (DIY), according to the Cremation Advisor posted in his article in July, 2018. As to the marketing aspect, [6] posited, the advertising of intangible offerings - mainly of unsought offerings consisting of the ones of the funeral enterprise - may be stated to pose inherently particular demanding situations to marketers. Because of the unsought nature of funeral offerings, clients usually keep away from the enterprise, by and large due to the fact the offerings supplied via way of means of the funeral enterprise are related to dying and grief [21]. Argue that the advertising issue of a internet site facilities on the provision of facts approximately an organization's services and products to potential consumers. However, if using the internet site does now no longer cause the era of recent business, it'd just as properly be deemed to be redundant, [22], in addition, states that it's far vital for a business, inclusive of funeral homes, to have on-line visibility within side the modern-day market.

\section{Research Question}

1. To what extent do the respondent death care businesses utilize the following strategic actions with regard to strategies implemented; strategies evaluated and change of strategies

2. To what extent do the respondent death care businesses respond to SWOT, PESTEL and Porter's Five Forces Model?

3. How do the respondent death care businesses leverage their actions on the following growth drivers: market, product/service; customer and resource positioning?

4. Is there a significant difference in the responses of the selected death care businesses in terms of leveraged actions on the identified growth drivers?

\section{Methodology}

To enable to determine the growth drivers of death care businesses, the researcher used descriptive-evaluative study and employed mixed method to gather valid information relevant to present conditions and thereby formulate alternative strategic management plans. This study used the analysis of SWOT, PESTEL, Five Forces Porter's model and the balanced scorecard. These are empirically validated strategic management tools. This paper examined the present vision and mission statements of several Filipino based funeral businesses, identified using tacit and explicit knowledge management processes (KM), and were recognized that the application of critical success have improved market penetration, increase company leverage and stain ability of the firm. The researcher used a randomly selected respondent funeral directors, and funeral officers who have worked during the time of the conduct of research. They had a total of fifty (50) respondents coming from the different departments of the selected funeral home companies in Metro Manila. The respondents included the Presidents and Vice Presidents of the three selected funeral companies.

\section{Related Literature}

\subsection{Death Care Industry}

The death's report reached to 579,237 [17]. The figure is equal in value of a crude death rate (CDR) there are at least individuals of six per in a population of thousand. Indeed year 2015, an average of 1,587 die per day. It implies sixty six individuals die on hourly basis or in a minute. Funeral care in the Philippines is a large and growing industry. The cost for funeral practice ranges from 416,00 and 520,000 pesos. This business is viewed by most as an uncongenial light. The ghoulish activity of this business cannot be undermined when 
it comes to ROI.

The figure 1 depicts that out of 10,065 total establishments for the sector beauty salon has the highest percentage of 30.7 , while the funeral services got $14.6 \%$ which represented is placed $4^{\text {th }}$ in the ranking with 1,477 establishments in the
Philippines, other is all other industries with $25.8 \%$, washing and dry cleaning of textile and fur products with $15 \%$, beauty treatment and personal grooming activities with $4.6 \%$, and lastly is spa activities with $93 \%$.

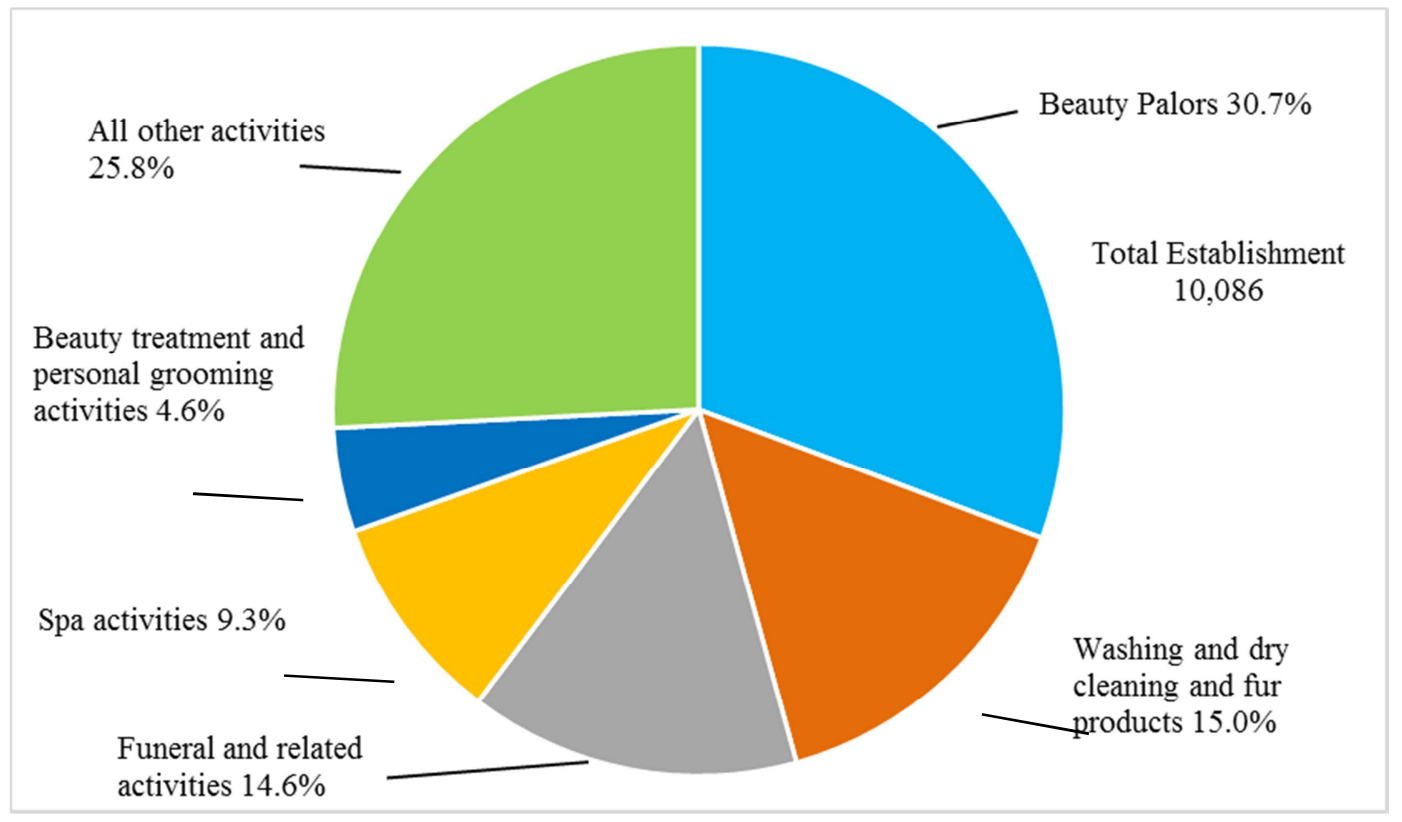

Figure 1. PSA 2015.

Revenue is expected to increase at an annual rate of $1.2 \%$ to $\$ 16.7$ billion, including $0.6 \%$ growth projected over 2019 alone. Competition in this industry continue to soar among entrepreneurs venturing on this business, inflation or the annual price increases of primary and allied products and services is practically ensured. Figure 2 illustrates that Funeral and related activities had obtained a 10,426 , out of total employment of 77,581 as shown below.

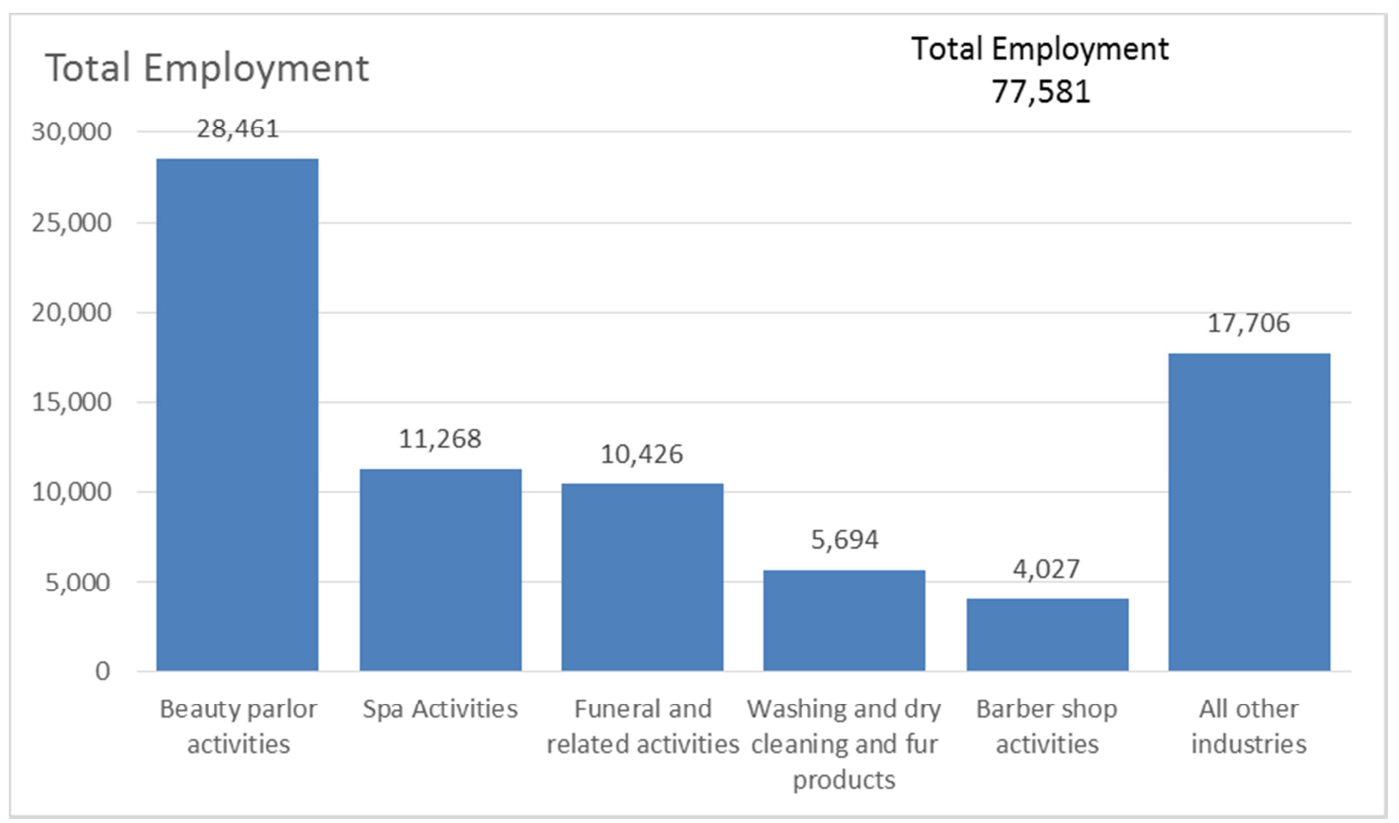

Figure 2. Distribution of Employment by the Sector by Industry sub class. Source: PSA 2015.

As shown on Figure 3, total income reached to 4.9b income and $4.2 \mathrm{~b}$ for expenses by industry group. Personal services for wellness, except sports activities has a 35.6 billion income, and 30.8 billion expenses, with profit of 4.8 billion, funeral and related activities has total income of 4.9 billion and 4.2 billion expenses with the profit of 7 billion, while repair of personal and household goods, has 3 billion profit, repair of computers and communication equipment with 1 billion profit, 
laundry service 3 billion profit, and lastly, the domestic services and other personal service activities with no profit.

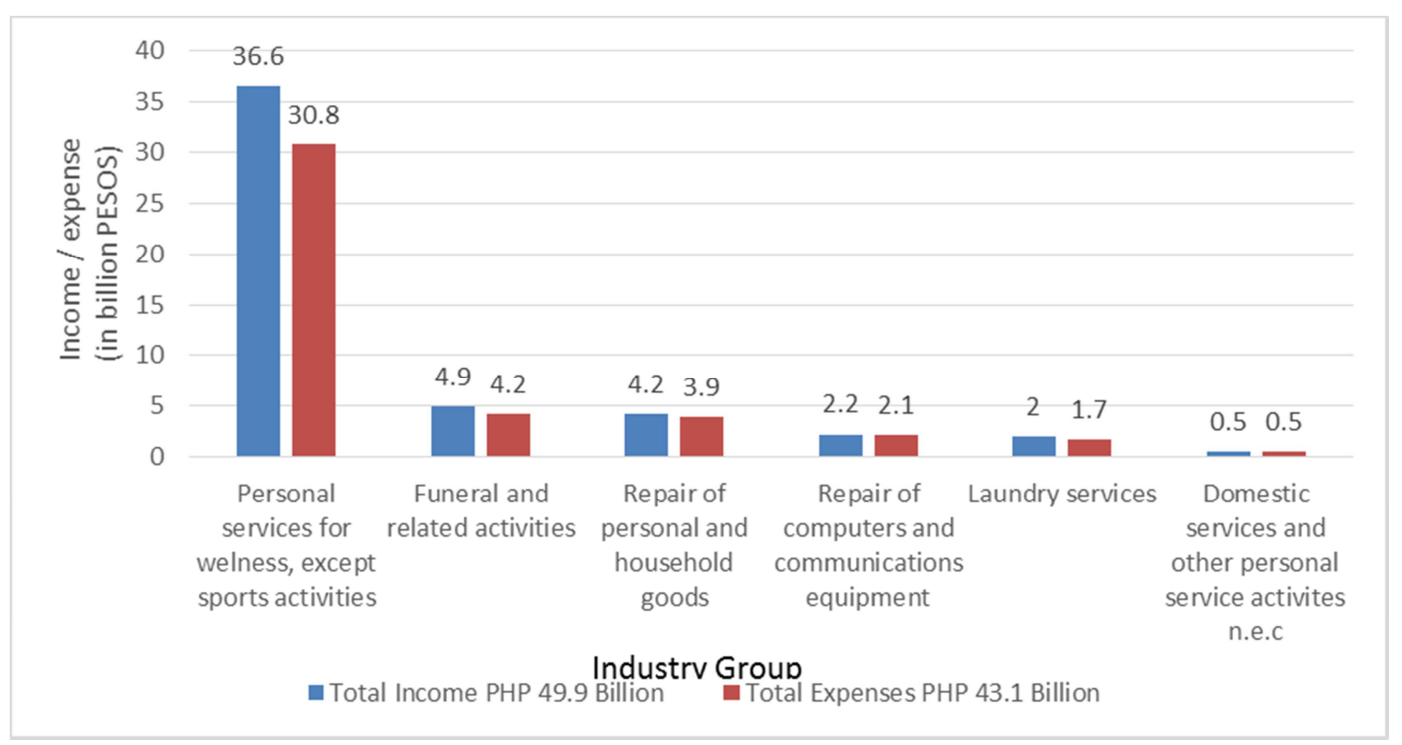

Figure 3. Distribution of income and expense, PSA 2015.

\subsection{External Growth Drivers}

a. Aging population. Seven percent $(7 \%)$ are considered aging in most countries or over 65 years old [19]. It is expected that health conditions of aging population in the Philippines shall face a challenge with regard to health care system because it is increasing in number. These conditions shall include diabetes, obesity, dementia, cancer, dementia, heart disease, arthritis, stroke which certainly have great impact in the death care businesses. Perez, the Director of Commission on Population Development, CPD)'revealed that senior citizens in the country ages from 60 years old and above is currently representing 8.2 percent of the population, that means, Philippines is "beginning to age." When it reaches 14 per cent, for the senior citizens' population then the society is aging. It is expected to hit 14 per cent between year 2030 and 2035, Perez said, less than 20 years from now.

b. Strong economic growth. According to ADB report in 2017 the Philippine economy shall experience robust economy. Unemployment rate is low, a remittances rise, and inflation is an ideal rate. The economic growth may be attributed to increased public investments in infrastructure and social services. The economy of the Philippine is in robust status with private and public investment fueling strong economic this year and tomorrow," said ADB Country Director for the Philippines Mr. Kelly Bird" (www.adb.org/news/strong-domestic-demand-fuel-faster-phil fppine-growth-2019-adb

c. Increase in Disposable Income. Disposable income is the amount left to the household after the taxes and mandatory charges have been deducted that will be available for spending and savings https://psa.gov.ph/survey/annual-poverty-indicator

d. Steady Population Growth. The Philippines' population grows steadily. Having rank as number country with a rate grew by $1.72 \%$ between 2010 and 2015 . The population for current years is 108.12 million, according to the latest UN estimates.

e. Increase in Death Rate The death rate continue to increase in 2016, the recorded number death was 582,183; this implies that it has a daily death of 1,591 , it goes 66 deaths every hour and one person every minute dies [18].

\subsection{Internal Growth Drivers}

\subsubsection{Strategic Planning}

Strategic Planning is the art and science of formulating, implementing, and evaluating cross functional decisions that enable an organization to achieve its objectives [9].

\subsubsection{Vision and Mission Core Values}

According to [9], the vision statement always tells" what do want to become in the future?". It is in a long term basis. On the other hand, the mission is the foundation of the business. The reason for its existence. It answers the question "what is our business?" Usually in a short term basis. It can be argued that it is profit, not mission or vision is the primary corporate motivator. Vision, mission, and core values can break and make the company once the delivery is not clear to the organization. Core values are means to achieve the vision and mission of the organization.

They are statements that suggest or determine what a company inspires to be, are visions, and generally include a specific time frame, for example, within ten years; whereas missions denote what goals it expects to achieve in a timely manner. The vision is usually thought of what the company wants to become, and the mission more specifically what knowledge management processes will be incorporated in its implementation order to achieve its goals, objectives, and aspirations. According to [7], it is defined as future foresight of what the organization would like to become in the future, while mission serves as the main reason why organization exist because it has purpose that will guide the company. Also, mission tells the company's business in 
nature.

During these turbulent times a firm should be well versed as to what changes, or modifications should be implemented in order to avoid a financial pitfall [3]. The process of reevaluation is paramount, examining present data, using a designated financial ratio base for comparative analysis, and also employing the forecasting techniques, in increments of at least five - ten years.

Mastery of this tool is, without a doubt, composed of many components' some used more extensively than others, but certainly used by most successful business enterprises [14]. Research has revealed strategic management is an integral part of the critical success formulation process, and will, more often than not, determine the future outcome of a firm, [9].

Some of the most popular components of strategic management, are also referred o as knowledge management (KM), critical success factors, include the SWOT analysis, financial ratios, the balanced score-card, PEST analysis, and various matrices, most notably the quantitative strategic planning matrix, which offers selective alternative strategies [13]. Some firms will use a combination of these components and include Porters' Five Forces of competition model, which identifies immediate threats to a firm, notably competitive rivalry, the threat of new entrants, supplier bargaining power, customer bargaining power, and substitute products. A firm would benefit tremendously by utilizing these components and the competition model. The strategic tool of Five forces by Michael Porter's completion will help a firm make meaningful decisions, make necessary adjustments, and systematically apply measures, critical success factors, that will enhance and promote its industry growth and corporate leverage [9].

Implementing Strategy Formulation. This is the final execution of the action taken to meet the long term goals of the organization. In the implementation of strategy, the strategic mangers change the chosen strategy into the deliverables, movables and manageable.

SWOT analysis. Is powerful that determines the strengths, weaknesses, opportunities, and Threats both the internal and external environment. Using this tool will be able to formulate and implement a new strategy. [24]

Porter's Five Forces Model. This model has powerful implications for both strategy and competitive advantage. It enables leaders to keenly analyses and understand the industry environment and shape the organization's strategy. As the rule says, the stronger the five forces, the lower the company's profit potential [20].

Balance Scorecard. This is used in assessing management performance. This tool is utilized to appreciate the application of strategic management with the identification and improvement of the varied internal environment of business and resulting from external results. Balance Scorecard. This is used in assessing management performance. This tool is utilized to appreciate the application of strategic management with the identification and improvement on varied internal environment of a business and resulting from external results. [10].

\section{Result and Discussion}

\subsection{Extent of Strategic Action Utilization}

Strategies Implemented. It indicates that all items under this aspect were rated 'great extent', emphasizing that any available strategic formulation which can be applied and utilized by a certain construction company would definitely be adopted as to address competition. The grand mean of 3.93 suggests that Funeral companies are trying to implement the aforementioned strategies based on their usefulness and applicability to the company's situation. Market Development obtained the highest mean of 4.00 indicated great extent.

Strategies Evaluated. Shows that the grand mean of 3.81, interpreted as 'great extent' suggest that all implemented strategies were also evaluated for their utility to the company's situation.

Change of Strategies. It shows that all strategies implemented can be changed after it was evaluated by top management [1]. This was attested by the result of the grand mean of 3.65 interpreted as 'great extent'. It leads to an inference that top management always have the privy to change of alter their strategic actions as they deemed necessary to compete and address present and future situations.

\subsection{Extent of Response to Internal and External Business Stimuli}

Strengths. Implies the responses of selected death care businesses to their strength. The grand mean of 3.98 suggests that these selected companies utilized their strength to 'great extent'. It can be noted as well that 'good customer service' was rated 'very great extent', indicating a very powerful strength for a funeral company.

Weaknesses It can be noted that 'poor advertisement' was rated 'moderate extent'. Both big and small funeral companies do not make any advertisements on the radio, tv, and social media though they may have an effective marketing program, they usually rely on the word of mouth advertisement.

Opportunities. For small scale funerals they may have better opportunities by utilizing new technology and branch expansion with the highest mean of 4.09 and 4.06 for branch expansion respectively with a grand mean of 3 . This suggests that the funeral directors must focus on technology and branch expansion to create more opportunities in business.

Threats. The responses on threats has a grand mean of 3.27 interpreted as 'moderate extent' suggest that in totality death care companies are moderately affected by threats. However, the most salient factor that may influence their strategic action would be 'entry of new competition' (great extent), which brings forth diminishing market share and disruption to core competencies among the existing firms should a new entrant possess higher technological prowess.

Table 1 shows the PESTEL factors faced by the respondent death care companies. PESTEL factors are very important to consider as they affect the totality of the business operation. Thus this was rated 'great extent' in all items by the respondents having a grand mean of 3.95 also 'great extent'. 
Table 1. PESTEL Factors.

\begin{tabular}{llll}
\hline & Mean & SD & Int \\
\hline Political & 3.94 & .41606 & GE \\
Economic & 3.98 & .51368 & GE \\
Socio-cultural & 3.94 & .41606 & GE \\
Technology & 3.93 & .44533 & GE \\
Legal & 3.97 & .42604 & GE \\
Grand Mean & 3.95 & & GE \\
\hline
\end{tabular}

Table 2 All items under this aspect were also rated 'great extent' with a grand mean of 3.61 Porter's five forces model suggest that a firm has five forces to face when it conducts its business, thus, each force shall be addressed properly as it affects one important aspect of the operation. The great extent impression suggests that the death care businesses need a thorough analysis that may have a profound impact on an organization's performance.

Table 2. Porter's Five Forces.

\begin{tabular}{llll}
\hline & Mean & SD & Int \\
\hline Customer's power & 3.41 & .67485 & GE \\
Seller's power & 3.53 & .75635 & GE \\
Substitute products & 3.75 & .68430 & GE \\
Potential entrants & 3.60 & .67403 & GE \\
Rivalry of firms & 3.76 & .83753 & GE \\
Grand Mean & 3.61 & & GE \\
\hline
\end{tabular}

\subsection{Leverage Actions on Growth Drivers}

Table 3 indicates that the respondent death care companies have a 'strong' leverage on market positioning. Market positioning is vital in gaining a niche and wider share of the funeral industry market necessary for growth of revenue. It has 2.91 grand mean.

Table 3. Market position.

\begin{tabular}{llll}
\hline & Mean & SD & Int \\
\hline Market share & 2.83 & .51368 & $\mathrm{~S}$ \\
Market participation & 2.94 & .42862 & $\mathrm{~S}$ \\
Price leadership & 2.97 & .38239 & $\mathrm{~S}$ \\
Grand Mean & 2.91 & & $\mathrm{~S}$ \\
\hline
\end{tabular}

Table 4 shows the responses of the funeral companies with regard to product positioning. This aspect was rated 'strong' as indicated by the grand mean of 2.87 . Product positioning or more specifically services offered by construction companies matters a lot in gaining popularity, client acquisition and expanding its market base
Table 4. Product position.

\begin{tabular}{llll}
\hline & Mean & SD & Int \\
\hline Protected position & 2.89 & .32280 & $\mathrm{~S}$ \\
Differentiation & 2.83 & .38239 & $\mathrm{~S}$ \\
Product line breath & 2.89 & .32280 & $\mathrm{~S}$ \\
Technology & 2.89 & .32280 & $\mathrm{~S}$ \\
Grand Mean & 2.87 & & $\mathrm{~S}$ \\
\hline
\end{tabular}

Table 5 shows the responses of the selected death care companies with regard to customer position. This aspect obtained a grand mean of 2.82 interpreted a "strong" Customer relationship is tied with forward integration with a mean of 2.83 . These two may be good components in funeral business.

Table 5. Customer position.

\begin{tabular}{llll}
\hline & Mean & SD & Int \\
\hline Brand reputation/image & 2.77 & .42604 & $\mathrm{~S}$ \\
Breath/diversity of customer base & 2.80 & .40584 & $\mathrm{~S}$ \\
Special customer relationship & 2.83 & .38239 & $\mathrm{~S}$ \\
Forward integration & 2.83 & .38239 & $\mathrm{~S}$ \\
Marketing \& sales & 2.89 & .32280 & $\mathrm{~S}$ \\
Grand Mean & 2.82 & & $\mathrm{~S}$ \\
\hline
\end{tabular}

Table 6 shows the responses with regard to resource position. It can be inferred from the table that the grand mean of 2.83 suggests a 'strong' response coming from respondent death care businesses. These resources are quite essentials for capital investment

Table 6. Resource position.

\begin{tabular}{llll}
\hline & Mean & SD & Int \\
\hline Cost position & 2.89 & .47101 & $\mathrm{~S}$ \\
Resource capacity \& distribution & 2.86 & .49366 & $\mathrm{~S}$ \\
Backward Integration & 2.80 & .40584 & $\mathrm{~S}$ \\
Resource acquisition ability & 2.69 & .47101 & $\mathrm{~S}$ \\
Special supplier relationship & 2.83 & .51368 & $\mathrm{~S}$ \\
Relationship with stakeholders & 2.94 & .41606 & $\mathrm{~S}$ \\
Grand Mean & 2.83 & & $\mathrm{~S}$ \\
\hline
\end{tabular}

\subsection{Significant Responses in Terms of Leveraged Actions on the Identified Growth Drivers}

Table 7 shows that all items under the aspect of market positioning are 'significantly' different among selected death care companies. It reveals that different death care companies would have their own distinct way of market positioning and grabbing a substantial amount of market share from the totality of the death care business.

Table 7. Significant Difference with Regard to Market Positioning.

\begin{tabular}{|c|c|c|c|c|c|c|}
\hline & Df & & $\mathbf{F}$ & p-value & Int & Decision \\
\hline & $\mathrm{BG}$ & 2 & & & & \\
\hline \multirow[t]{3}{*}{ Market share } & WG & 32 & 4.506 & .019 & Significant & Reject Ho \\
\hline & Total & 34 & & & & \\
\hline & BG & 2 & & & & \\
\hline \multirow[t]{3}{*}{ Market participation } & WG & 30 & 6.847 & .004 & Significant & Reject Ho \\
\hline & Total & 32 & & & & \\
\hline & BG & 2 & & & & \\
\hline \multirow[t]{2}{*}{ Pricing leadership } & WG & 32 & 4.467 & .019 & Significant & Reject Ho \\
\hline & Total & 34 & & & & \\
\hline
\end{tabular}


Table 8 reveals that differentiation is an aspect of product positioning that every funeral companies are conscious of. This item was revealed to have 'no significant' difference in the responses of the selected funeral companies.

Table 8. Significant Difference with Regard to Product Position.

\begin{tabular}{|c|c|c|c|c|c|c|}
\hline & Df & & $\mathbf{F}$ & p-value & Int & Decision \\
\hline \multirow{3}{*}{ Protected position } & BG & 2 & \multirow{3}{*}{5.257} & \multirow{3}{*}{.011} & \multirow{3}{*}{ Significant } & \multirow{3}{*}{ Rejected } \\
\hline & WG & 32 & & & & \\
\hline & Total & 34 & & & & \\
\hline \multirow{3}{*}{ Differentiation } & BG & 2 & \multirow{3}{*}{2.485} & \multirow{3}{*}{.099} & \multirow{3}{*}{ Not S } & \multirow{3}{*}{ Not Rejected } \\
\hline & WG & 32 & & & & \\
\hline & Total & 34 & & & & \\
\hline \multirow{2}{*}{ Product line breath } & BG & 2 & \multirow{2}{*}{5.257} & \multirow{2}{*}{.011} & \multirow{2}{*}{ Significant } & \multirow{2}{*}{ Rejected } \\
\hline & Total & 34 & & & & \\
\hline \multirow{3}{*}{ Technology } & BG & 2 & \multirow{3}{*}{5.257} & \multirow{3}{*}{.011} & \multirow{3}{*}{ Significant } & \multirow{3}{*}{ Rejected } \\
\hline & WG & 32 & & & & \\
\hline & Total & 34 & & & & \\
\hline
\end{tabular}

Table 9 shows that the items 'Special customer relationships', 'Forward integration', and 'Marketing and sales' has 'no significant' difference in the responses of the selected funeral companies. All death care companies believe that a special customer relationship coupled with the ability to hold the downstream movement of a business system would be vital in the growth and success of an enterprise.

Table 9. Significant Difference with Regard to Customer position.

\begin{tabular}{|c|c|c|c|c|c|c|}
\hline & Df & & $\mathbf{F}$ & p-value & Int & Decision \\
\hline \multirow{3}{*}{ Brand reputation/image } & BG & 2 & \multirow{3}{*}{5.297} & \multirow{3}{*}{.010} & \multirow{3}{*}{ S } & \multirow{3}{*}{ Reject Ho } \\
\hline & WG & 32 & & & & \\
\hline & Total & 34 & & & & \\
\hline \multirow{3}{*}{$\begin{array}{l}\text { Breath \& diversity of } \\
\text { customer base }\end{array}$} & BG & 2 & \multirow{3}{*}{3.679} & \multirow{3}{*}{.036} & \multirow{3}{*}{ S } & \multirow{3}{*}{ Reject Ho } \\
\hline & WG & 32 & & & & \\
\hline & Total & 34 & & & & \\
\hline \multirow{3}{*}{$\begin{array}{l}\text { Special customer } \\
\text { relationships }\end{array}$} & BG & 2 & \multirow{3}{*}{2.485} & \multirow{3}{*}{.099} & \multirow{3}{*}{ N S } & \multirow{3}{*}{ Not Rejectec } \\
\hline & WG & 32 & & & & \\
\hline & Total & 34 & & & & \\
\hline \multirow{4}{*}{ Forward integration } & BG & 2 & \multirow{3}{*}{2.485} & \multirow{3}{*}{.099} & \multirow{4}{*}{ N S } & \multirow{3}{*}{ Not Rejected } \\
\hline & WG & 32 & & & & \\
\hline & Total & 34 & & & & \\
\hline & BG & 2 & \multirow{3}{*}{1.162} & & & \multirow{3}{*}{ Not Rejected } \\
\hline \multirow[t]{2}{*}{ Marketing \& sales } & WG & 32 & & \multirow[t]{2}{*}{.326} & \multirow[t]{2}{*}{ N S } & \\
\hline & Total & 34 & & & & \\
\hline
\end{tabular}

Table 10 suggests that the items 'Cost position' and 'Resource capacity and distribution' are 'not significant' among the responses of the selected funeral companies.
Proper cost and resource usage is necessary to prevent exaggerated expenses which ma imperils a company's financial health

Table 10. Resource Customer Position.

\begin{tabular}{|c|c|c|c|c|c|c|}
\hline & Df & & $\mathbf{F}$ & p-value & Int & Decision \\
\hline \multirow{3}{*}{ Cost position } & BG & 2 & \multirow{3}{*}{1.002} & \multirow{3}{*}{.379} & \multirow{3}{*}{ NS } & \multirow{3}{*}{ Not Rejected } \\
\hline & WG & 32 & & & & \\
\hline & Total & 34 & & & & \\
\hline \multirow{3}{*}{$\begin{array}{l}\text { Resource capacity and } \\
\text { distribution }\end{array}$} & $\mathrm{BG}$ & 2 & \multirow{3}{*}{.891} & \multirow{3}{*}{.420} & \multirow{3}{*}{ NS } & \multirow{3}{*}{ Not Rejected } \\
\hline & WG & 32 & & & & \\
\hline & Total & 34 & & & & \\
\hline \multirow{3}{*}{ Backward integration } & BG & 2 & \multirow{3}{*}{4.392} & \multirow{4}{*}{.021} & & \multirow{3}{*}{ Rejected } \\
\hline & WG & 32 & & & \multirow[t]{3}{*}{$\mathrm{S}$} & \\
\hline & Total & 34 & & & & \\
\hline \multirow{3}{*}{ Resource acquisition ability } & BG & 2 & \multirow{4}{*}{5.072} & & & \multirow{3}{*}{ Rejected } \\
\hline & WG & 32 & & \multirow[t]{3}{*}{.012} & \multirow[t]{3}{*}{$\mathrm{S}$} & \\
\hline & Total & 34 & & & & \\
\hline \multirow{3}{*}{ Special supplier relationship } & BG & 2 & & & & \multirow{3}{*}{ Rejected } \\
\hline & WG & 32 & \multirow[t]{2}{*}{4.506} & \multirow[t]{2}{*}{.019} & \multirow[t]{2}{*}{$\mathrm{S}$} & \\
\hline & Total & 34 & & & & \\
\hline \multirow{3}{*}{$\begin{array}{l}\text { Relationship with } \\
\text { stakeholders }\end{array}$} & BG & 2 & \multirow{3}{*}{.618} & \multirow{3}{*}{.545} & \multirow{3}{*}{ NS } & \multirow{3}{*}{ Not Rejected } \\
\hline & WG & 32 & & & & \\
\hline & Total & 34 & & & & \\
\hline
\end{tabular}




\subsection{Fiver Forces Model}

\section{Rivalry Among Existing Firms: HIGH}

Funerals A, B, and $\mathrm{C}$ have been very active in the industry competition, which produces a high competition. Most recently, new independent players have started their commercial operations. A major reason for high competitive rivalry between all players is the fact that all the existing players have each own strategy

\section{Threat of Substitutes: $L O W$}

Several raw materials were substituted by products from China which are quite lower as compared to the leading brands But for some prime raw materials vary from seasons. The industry is taking lead to the clean air act policy of the government in which the majority of the products need change processes and upgrades. The small players have resistance since they have very limited resources. The three players have to adapt in order to compete effectively to enable them to attract more customers. So far, it's the only cremation as the most popular substitute for interment.

Threat of New Entrants- HIGH

Since the cost of entry in this industry is difficult, fewer new entrants are expected. The demand is high so the prices are high too. The idea to modernize the operations and the application of new technology will give chance the owners to dictate the price as this type of service is inelastic.

\section{Bargaining Power of Buyers: HIGH}

The consumers have high power with regard to selection as to which funeral service is best depending on their availability of the resources. Since the number of the funerals parlors is plenty they can choose which is according to their budget. Buyers face low no switching costs. Buyers are a big threat to the backward integration of the industry

\section{Bargaining Power of Suppliers: HIGH}

The supplier's power is high because the existing businesses face significant switching costs when changing suppliers. They offer products and services that are differentiated. The owners can directly threaten to forward integration into the industry.

Table 11 shows the comparative competitors' analysis which determines SWOT factors among the selected funeral companies in terms of financial capital, business strategies, technology, products and offered, pricing strategy and capabilities.

Table 11. Competitor's Analysis of the Selected Funeral Companies.

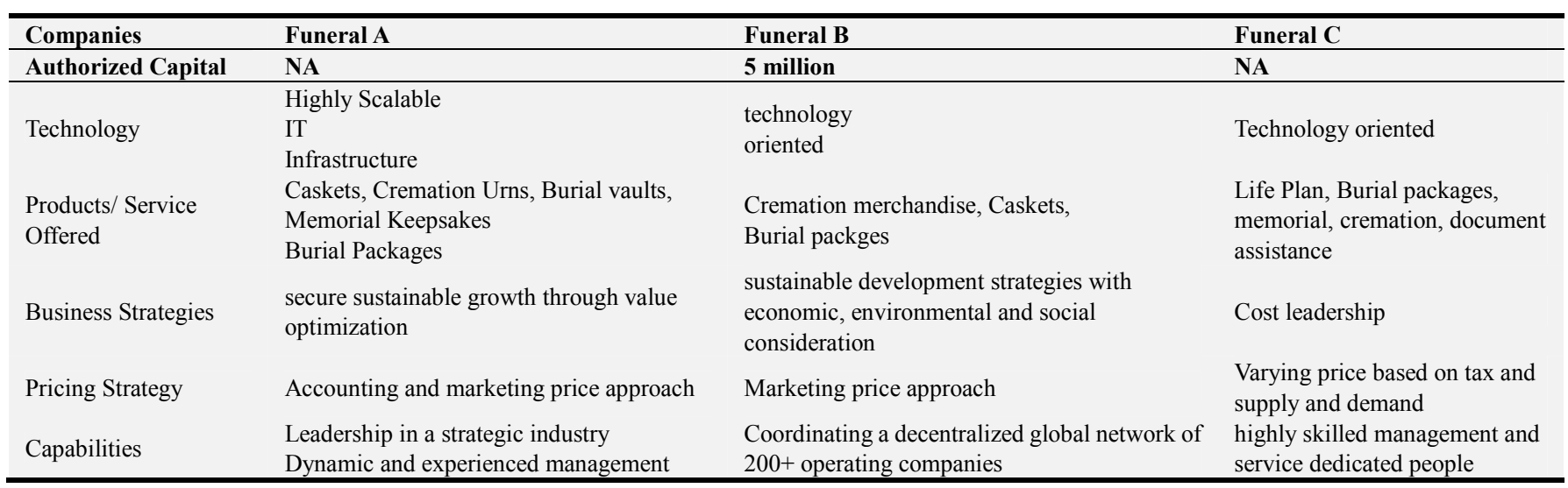

Market Development

Market development is bringing products and services into new location area.

Strengths/ Opportunities

Enables to tap new market segment

Increases Market Share

New Geographic Areas

Market development strategy is very essential for the companies in order to achieve its vision and mission of being the market leader in the Philippines. Geographical expansion is the most necessary for increasing market share. The company needs more franchising and, of course, needs depots for the smooth and sure supply of products to franchisees for geographical expansion in Luzon [24].

Strengths/ Opportunities

Increase market share

Attract non-users
Weaknesses/Threats

High operating expenses

Lack of market knowledge

Strong competitors in new market

Research and development until the unit must be aggressive to find out a new set of customers or market segments in Luzon, which will enable the company to tap new market

Market Penetration

Market penetration strategies include enhancement of promotional materials. They reach market to penetrate in order augment market share.

\section{Weaknesses/Threats}

Needs to pursue other strategy to grow after market approach saturation 
Convinces clients to use more of the products

Lower operating expenses

Enhances value added services to customers

It is implemented by the company in order to increase its market share, attract new users and clients. For this, the company needs to increase its marketing and advertisement expenditure It should increase the distribution and promotion of products to those areas where it easily attracts the customers. It should increase its sales force to convince the industrial and

\section{Strengths/ Opportunities}

Product modification through new features

Different options for different customers

New Product

\section{Integration Strategies \\ Forward Integration}

Forward integration is all about increasing control over

\section{Strengths/ Opportunities}

Strengthens the relationship with final customers

Higher profits

Raises barriers to entry

Improves supply chain coordination

Forward integration helps increase sales and hence profit. It invites more franchisees in Luzon, giving them better facilities, terms and conditions, looking over the stations in city where visibility of brand is possible. The company can strengthen the relationships with the customers through company owned or dealer owned retail stations. Finding out specific locations and improving the retail network in Luzon can be beneficial to the

\section{Strengths/ Opportunities \\ Ensures supply of the products \\ Improves supply chain coordination}

Assured quality, ensured supply, timely delivery and savings on transportation costs are very crucial for the company to be competitive.

\author{
Strengths/ Opportunities \\ Ensures competitive advantage through economies of scale \\ Increased market power \\ Helps increase market share \\ Reduction of competition
}

A good scorecard reflects the strategic plan of the organization, provides a framework that helps shape work behavior, allows each person to measure his/her individual performance, and gives data to make changes immediately so that performance is enhanced [13].

Financial perspective measures the degree of increase in customer value by introducing promos, rebates, etc, and maintaining growth. To measure these factors, yearly sales reports and profit reports can be used. [4] The consumer perspective measures customer satisfaction and customer commercial users in Luzon.

Product Development. An integral part of the success of any business. Done in order to come up with new products/services and acquire competitive advantage over rivalry.

\section{Weaknesses/Threats \\ High operating expenses \\ The risk of product failure}

distributors. The company can distribute the product by franchising [20].

\section{Weaknesses/Threats}

Over concentration on product

company

Backward Integration

Backward integration means increased control over the company's suppliers. If the company's suppliers are not reliable, then the company can move towards backward integration by relying on many suppliers rather than few suppliers.

\section{Weaknesses/Threats \\ May lack capacity balancing to ensure downstream operation}

\section{Horizontal Integration}

Horizontal integration seek ownership through merging and acquiring. They apply economies of scale.

\section{Weaknesses/Threats}

Management challenge

acquisition level. The level of customer satisfaction can be identified through the survey and the number of customer complaints. Surveys can be carried out and complaint records can be maintained by appointing employees for a survey and by training franchisees, respectively. More customers can be acquired by advertisements and also by introducing loyalty programs. The internal process measures how a company achieves operational excellence and the customer management process strengthens manpower for expansion strategy and improves the community and environment. To 
measure all these factors related to operations and management, internal audit and inspection is an essential tool. For strengthening manpower, training and development are very necessary and for society and the community, the company should perform the external audit. Learning and growth measure strategic competencies, strategic technologies, motivation and awareness through regular inspection and internal survey. To increase competencies, the company should provide training on services, provide reward and recognition, build empowerment, and constant communication between management and employees. [23].

Balance score card for Funeral A, Funeral B and Funeral C

\begin{tabular}{|c|c|c|c|}
\hline Perspectives & $\begin{array}{l}\text { Strategic Goals } \\
\text { Maximizing customer value }\end{array}$ & $\begin{array}{l}\text { Measurement } \\
\text { Market Sales }\end{array}$ & $\begin{array}{l}\text { initiative } \\
\text { Introduce promo }\end{array}$ \\
\hline Finance & Maintain Growth & $\begin{array}{l}\text { Yearly sales report } \\
\text { Sales income }\end{array}$ & Income from operations \\
\hline Customer & Customer satisfaction & $\begin{array}{l}\text { Survey } \\
\text { No. of Customers Complaints }\end{array}$ & $\begin{array}{l}\text { Train Franchisees } \\
\text { Promote brand via advertising }\end{array}$ \\
\hline & Customer Acquisition & $\begin{array}{l}\text { Sales report } \\
\text { No. of customer account }\end{array}$ & Introduce loyalty program \\
\hline & Operational excellence & Audit/Inspection & Train Employees \\
\hline Internal & $\begin{array}{l}\text { Customer management } \\
\text { processes }\end{array}$ & Audit/ Inspection & $\begin{array}{l}\text { Train Franchisees } \\
\text { Inspection of retail station }\end{array}$ \\
\hline Process & $\begin{array}{l}\text { Improve community \& } \\
\text { environment } \\
\text { Strengthening manpower for } \\
\text { expansion strategy }\end{array}$ & External audit & $\begin{array}{l}\text { Meet external authorities } \\
\text { Training and development }\end{array}$ \\
\hline $\begin{array}{l}\text { Learning and } \\
\text { Growth }\end{array}$ & $\begin{array}{l}\text { Strategic competencies } \\
\text { Strategic technologies } \\
\text { Motivation } \\
\text { Awareness }\end{array}$ & $\begin{array}{l}\text { Inspection } \\
\text { Inventory management } \\
\text { Internal survey }\end{array}$ & $\begin{array}{l}\text { Provide training on services } \\
\text { Analyze current order-delivery system } \\
\text { Reward \& recognition } \\
\text { Build empowerment } \\
\text { Constant communication between } \\
\text { management and employee }\end{array}$ \\
\hline
\end{tabular}

\section{Conclusions}

1. The marketing issue was investigated and observed that prospective clients found out that advertisements for funerals are imperative. They perceived word of mouth as the most convincing factor to create awareness in the realization of the death care industry.

2. Death Care companies enabled themselves to assert current business situations in order to develop appropriate strategic actions.

3. Death care business is stable, profitable and still growing in the Philippines. The death rate is increasing in the Philippines due to the growth drivers.

4. Filipinos tend to be open now in death realization such as preparing themselves in pre-need, life plans, funeral services, and memorial products.

5. Cremation becomes popular. It has jumped five times.

\section{Recommendation}

1. To grow the marketplace for funeral services and increase the entire or primary demand for the services, companies within the sector have to educate consumers on the benefits of using professional funeral service providers as hostile making and handling all internment or cremation arrangements themselves. Emphasis should be placed on communicating clearly significant benefits that might accrue to users of the services. Companies within the sector should begin to cooperate and pool their resources to confirm that information on funeral services reaches as many consumers as possible.

2. Cooperation between companies would strengthen the industry position and enable the industry to petition the govt to deal with problems directly owing to it like allowing unlicensed companies and people which don't pay tax to continue operating to the detriment of honest, legitimate companies which contribute to income through tax.

3. Many companies within the sector also indicated that one among their main problems is lack of awareness within the market of the services they provide. Clearly word of mouth alone won't lead to high awareness within the market. Companies should therefore explore other ways of informing consumers of the range of services offered. Examples include radio and medium advertising, which is cost effective with more reach than television. Those companies that succeed in clearly differentiating themselves are those which will be ready to command premium pricing and build loyalty within the market.

4. Due to the peculiar nature of funeral services which are normally required by consumers when they are grieving after the death of their loved ones, the industry has to develop a code of ethics to manipulate how companies provide funeral services to forestall potential exploitation of consumers by unscrupulous companies. within the long term this may enhance the professional image of funeral service providers within the market.

5. The industry must standardize the idea of pricing which 
companies use. This will facilitate easier comparisons between the services offered by different companies and encourage more efficient companies to reap the advantages of more cost effective pricing 6. Apply market penetration to seek increase market share; employ market development strategy to introduce present products \&services into new geographic area.

\section{References}

[1] Abetti Pier A (2011). Technology Management, Rensselaer Polytechnic Institute (RPI) - Lally School of Management \& Technology, John Wiley \& Sons, Inc., Hoboken, New Jersey ADB Report https://www.adb.org/documents/adb-annual-report-2017.

[2] Amadis, M. G. (2014). Death care industry is big business. https://business.inquirer.net/164015/death-care-industry-is-big -business.

[3] Badilla, Maricel A. (2015) Tourism marketing, Rex Store, Manila bworldonline.com/content.php.section 2017.

[4] Cabrera, Elenita, B (2016) Management advisory services, cpa reviewer. Conanan Educational Supply, Philippines Coetzee, Maree \& Van Heerden (2014) The marketing of an unsought service through an unobtrusive medium: a content analysis of the websites of members of the National Funeral Directors Association of South Africa, Communicare, Volume 33.

[5] Clapano (2017) Manila funeral home faces closure over rotting corpses.

https://www.philstar.com/metro/2017/09/15/1739547/manila-f uneral-home-faces- closure-over-rotting-corpses.

[6] Coetzee, CA, Maree, T and Van Heerden, H. 2014. The marketing of an unsought service through an unobtrusive medium: a content analysis of the websites of members of the National Funeral Directors Association of South Africa. In Communicare: Journal for Communication Sciences in Southern Africa, 33 (1), pp 35-56.

[7] Daniel Robin (2010) Developing Vision, Mission, Core Values. https://2012books.lardbucket.org/books/management-principl es-v1.1/s08-developing mission-vision-and-.html.

[8] Davenport, T. H. and Prusak, L. (1998). Working knowledge: how organizations manage what David, Fred R (2017) Strategic management, concepts and cases, Pearson Education, USA.

[9] David, F. (2017). Strategic Management concepts and cases $14^{\text {th }}$ edition.

[10] Evan, James, R. (2016) Total Quality. Strategic management, concepts and cases, Prentice Hall, Philippine edition, Management, Cengage Learning, Philippines Guerero (2014).
Death care industry is big business. https://business.inquirer.net/164015/death-care-industry-is-big -business.

[11] Gurerrero, M., Cunninghan, J., Urbano, D. (2014). Economic impact of entrepreneurial universities' activities: An exploratory study of the United Kingdom.

[12] https://www.valueline.com/Stocks/Industries/Industry_Overvi ew_Funeral_Services.aspx\#.Xznr8OgzbIV 2016.

[13] Kaplan, Robert \& Norton, David (2001), Transforming the Balanced Scorecard from Performance Measurement to Strategic Management: Part II. American Accounting Association Accounting Horizons Vol. 15 No. 2 June 2001. Marketreport.online.com 2017.

[14] Mason, Bob ((2011) The Environmental Scan - A Different Approach, Retrieved from http://ezinearticles.com/?The-Environmental-Scan---A-Differe nt-Approach\&id=2213058 Retrieved on June 16, 2011.

[15] Mellen, 2018 Molecular mechanisms of cell death: recommendations of the Nomenclature Committee on Cell Death. https://www.nature.com/articles/s41418-017-0012-4.

[16] Monares, Aicel Joy (2018), Marketing strategies and practices of selected funeral homes in caloocan city. Unpublished thesis, Philippines Philippine Statistic Authority (2017). Registered deaths in the Philippines Philippine Daily Inquirer, Death care industry, inquirer.net, February 2014.

[17] Philippine Statistic Authority (PSA) 2015. www.psa.gov.ph/tags/death-statistics.

[18] Philippine Statistic Authority (PSA) 2019. www.psa.gov.ph/tags/death-statistics.

[19] POPCOM (2017). Philippines moving toward aging population https://news.abs-cbn.com/news/01/03/18/philippines-moving-t oward-aging-population-popcom.

[20] Rothaermel, Frank T. (2017) Strategic management, $3^{\text {rd }}$ edition, Mc Graw Hill, USA.

[21] Swanepoel, J. \& Bothma, C. (2013). Fundamentals of e-marketing $\left(2^{\text {nd }}\right.$ ed. Cape Town: Juta.

[22] Waters, P. C. (2009). Staying accessible: the value of a web presence in funeral service. Unpublished Master's dissertation, Ball State University, Muncie, Indiana, USA.

[23] Williams, S. (2012). Marketing your funeral home through aftercare and community relations programs. Funeral business advisor. Retrieved June 2, 2012 from $\mathrm{http}: / /$ www.funeralbusinessadvisor.com/?p=5042(www.pharm acytimes.com/publications/issue/2016.

[24] Ybanes, Antonio Errol, (2014) Applied Stategic management and business policy: A case study, Katha Publishing, Manila. 